\title{
Distribution patterns and trophic characteristics of salmonids and native species inhabiting high altitude rivers of Pampa de Achala region, Argentina
}

\author{
Ricardo A. Ferriz ${ }^{1}$, Claudio R. M. Baigún ${ }^{2}$ and Jael Dominino ${ }^{3}$
}

The Pampa de Achala in central Argentina is an area with low fish species richness where salmonids were first introduced at the beginning of the twentieth century. A total of 19 rivers of different order were sampled during the low water period by using portable electrofishing equipment. We covered different identified macrohabitats (pools, riffles, glides and cascades) in reaches of 300-500 m length. The native species Trichomycterus corduvensis and two exotic salmonids such as Salvelinus fontinalis and Oncorhynchus mykiss represented the most common species, showing allopatric and sympatric distribution in some streams. Stomach contents and diet overlapping were also analyzed. Cluster results showed a first main group comprised those streams with high diet similitude between T. corduvensis and $O$. mykiss whereas a second main group consisted of streams with high diet similitude between $O$. mykiss and S. fontinalis. Mean niche width was similar among all these species but $T$. corduvensis showed that widest range whereas $S$. fontinalis exhibited the narrowest trophic niche. We were able to document a direct predation on $T$. corduvensis by $O$. mykiss in two stream although distribution overlapping among native and exotic species were low. In turn diet overlapping among species were negligible. Trophic niche amplitude of $S$. fontinalis was inversely related to stream order, providing clues that geomorphology and hydrology may exert also influence of trophic characteristics and can be used for predicting the potential for food competition with native species. Analysis by Tokeshi plot revealed that $T$. corduvensis ranged from specialist to generalist whereas both salmonids showed generalist feeding habits with a heterogeneous and homogeneous diet.

El área de Pampa de Achala, en el centro de Argentina, posee una baja riqueza específica y donde los salmónidos fueron introducidos al comienzo del siglo XX. Se muestrearon 19 ríos de diferente orden durante el período de aguas bajas utilizando un equipo de pesca eléctrica portátil. Se cubrieron diferentes macrohábitats (pozones, correderas, tablas y cascadas) en tramos de 300 a 500 m de longitud. Las especie nativa Trichomycterus corduvensis y dos salmódios exóticos, Salvelinus fontinalis y Oncorhynchus mykiss, representaron las especies más comunes mostrando distribuiciones alopátricas y simpátricas en algunos de estos ríos. Se analizaron los contenidos estomacales y la superposición de sus dietas. El análisis por agrupamiento puso en evidencia un primer gran grupo compuesto por aquellos ríos con alta similitud de dieta entre T. corduvensis y $O$. mykiss, ancho medio de nicho fue similar entre estas especies pero T. corduvensis exhibió el rango de mayor amplitud y $S$. fontinalis que la superposición de distribución entre especies nativas y exóticas fue escasa. Por su parte, la superposición de dietas entre estas especies fue muy baja. La amplitud de nicho trófico de $S$. fontinalis estuvo inversamente correlacionada con el orden del río, proporcionando indicios que la geomorfología y hidrología podrían influir sobre las características tróficas y podrían ser utilizadas para predecir la competencia potencial con las especies nativas. El análisis mediante gráficos de Tokeshi reveló que T. corduvensis se comportó como especialista a generalista mientras ambos salmónidos mostraron hábitos generalistas con dietas homogéneas y heterogéneas.

Key words: Trophic niche, Pool and riffles, Sympatry and allopatry, Central Argentina.

${ }^{1}$ MACN - Museo Argentino de Ciencias Naturales “Bernardino Rivadavia”. Av. Angel Gallardo 470, C1405DJR, Buenos Aires, República Argentina.rferriz@macn.gov.ar.

${ }^{2}$ APN - Administración de Parques Nacionales, Delegación Regional Centro. Av. Richieri 2298, C5000, Córdoba, República Argentina. jdominino@apn.gov.ar

${ }^{3}$ INTECH - Instituto Tecnológico de Chascomús, Camino de Circunvalación Laguna, Km 6, 7120 Chascomús, Provincia de Buenos Aires, República Argentina. claudiobaigun@intech.gov.ar 


\section{Introduction}

Introduction of salmonids to Argentina has been a long practice since the beginning of twentieth century (Baigún \& Quirós, 1985). These species have successfully expanded particularly across the south of Argentina (Patagonia) and west mountain areas of Argentina where suitable environmental conditions allowed them to colonize glacial lakes and cold water rivers (Pascual et al., 2002, 2007; Vigliano \& Alonso, 2007). In other regions of the country with temperate or even subtropical climate salmonid distribution was confined to only high altitude rivers exhibiting suitable water temperature and flow conditions. Such scenario is observed in Córdoba Province where rainbow trout (Onchorhynchus mykiss) and brook trout (Salvelinus fontinalis) were successfully stocked after successive releases in many streams (Baigún \& Quirós, 1985). However, knowledge of both salmonid and native species composition in high altitude Córdoba rivers is still fragmentary, being most of fish records supported by surveys in middle altitude streams (1000 to 1500 m). For example Bistoni \& Hued (2002) analyzed species richness with regard to height in the Primero, Segundo, Tercero and Cuarto river basins concluding that such areas represent "trout zones" due to the fact that only few native species mostly belonging the Loricariidae and Trichomycteridae families were found. In turn, Pampa de Achala streams are located in high altitude areas (1500 to $2200 \mathrm{~m}$ ) where Haro \& Bistoni (1996) highlighted the importance of salmonid species as the basis of an important recreational fishery. Such previous studies however were focused on fish distribution patterns without considering the potential interactions between native and exotic species. Impacts of introduced salmonids represent a main concern and have been addressed in different Southern Hemisphere areas (Tilzey, 1976; Krueger \& May, 1991; Flecker \& Towsend, 1994; Townsed, 2003; Jackson et al., 2004; McDowall, 2006) even in high altitude rivers (McDowall, 2003). Specifically there is a vast literature documenting the impact of salmonids on native fish species in southern hemisphere rivers mainly in New Zealand (e.g., McDowall, 1990; Townsend \& Crowl, 1991), Australia (Jackson, 1981) and also Tasmania (Ault \& White, 1994).

In Argentina most of studies related to native-exotic interactions were focused on Patagonian basins (Pascual et al., 2002; Pascual \& Ciancio, 2007) but not reliable data have been gathered for other areas where such information would be of critical importance for fishing regulations and stocking policies of exotic species and for protection of native fish fauna. Moreover, unlike Patagonian streams where rainbow trout represent by far the dominant salmonid species (Baigún \& Quirós, 1985; Pascual et al., 2002), high altitude river from Córdoba Province may exhibit a noticeable presence of $S$. fontinalis thus precluding to generalize observed impacts in other basins.

The aim of this study is provide information about exotic salmonid distribution patterns inhabiting high altitude streams of the Pampa de Achala region and to attempt to determine on the extent such species may interact with native fish based on comparative trophic characteristics.

\section{Material and Methods}

The study area encompassed the Achala Hydric Reserve and the Quebrada del Condorito National Park both (Fig. 1). A total of 21 rivers of different orders were sampled during July and August of 2005 and 2006 where they exhibit low flows, thus allowing a clear differentiation of main macrohabitat units. Such environmental scenario differ from summer period when high flow limits macrohabitat identification and fish sampling. At each stream reaches of $500 \mathrm{~m}$ were selected to perform basic limnological characteristics, habitat inventory and to obtain biological information. Habitat units were identified as pools, riffles and glides by following Bisson et al. (1984) guidelines. A random subsample based on $50 \%$ of detected habitats was selected to perform detailed environmental measurements (three times per day and twice during each sampling year) following Bain \& Stevenson (1999) guidelines and to estimate fish abundance and density in random selected macrohabitat units. Such units were surveyed by setting

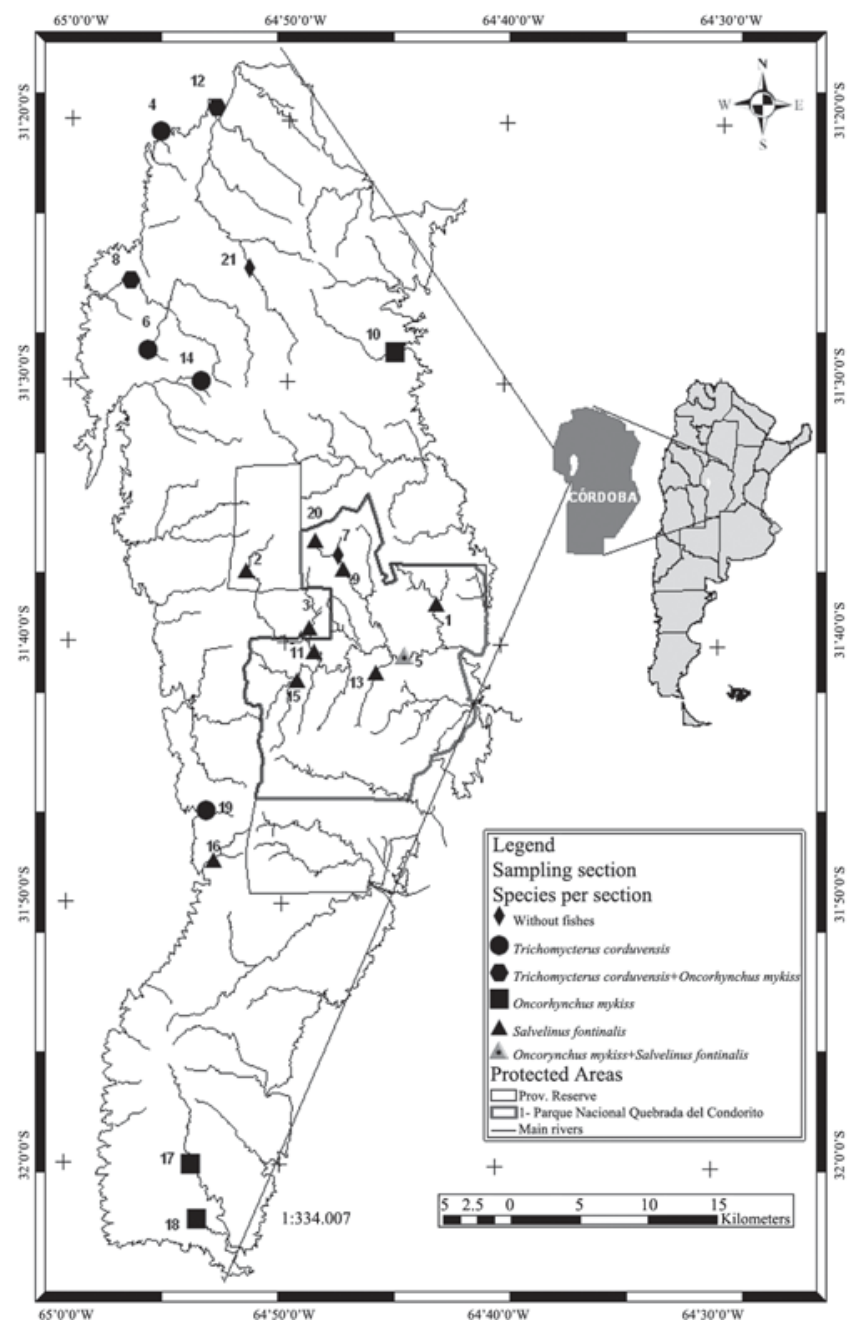

Fig. 1. Sampling sites and surveyed rivers in the Reserva Provincial Pampa de Achala and Quebrada del Condorito National Park. 
block nets and three consecutive passes of equal effort were performed with portable electrofishing equipment. Fish density was estimated using the Zippin method (1958) based on three removal passes. Limnological characteristics between streams inhabited by salmonids and non salmonids were contrasted by using non parametric Man Whitney test.

Total length and weight were measured for each specimen and the digestive tract of each specimen was preserved in 5\% formaline. Stomach contents were analyzed for all surveyed streams except Antena stream applying gravimetric methods, using a scale of $0.1 \mathrm{~g}$ precision. The quantification of the diet's main components followed the recommendations in Windell \& Bowen (1978) and Hyslop (1980). Given that any of these techniques alone are insufficient to display the diet importance (Windell \& Bowen, 1978; Berg, 1979; Hyslop, 1980), they were combined by means of the abundance index (IA) (Oda \& Parrish, 1981). This index is defined as \% FO \% P / 100 being FO the percentage frequency of a specific food item and $p$ the weight of each item in the diet expressed as a percentage. This index varies between 0 and 100 , with an item of IA $<10$ considered rare, $10<$ IA $<25$ occasional, $25<$ IA $<50$ essential and IA $>50$ dominant. The vacuidad index (\%VI) was built according to Molinero \& Flos (1992), being calculated as a percentage of empty alimentary tracts.

The feeding habits of each species were determined by Tokeshi analysis (Tokeshi, 1991), which relates individual to population level niche width. However in this case we modified the analysis by plotting the population feeding diversity (PD) against the mean individual feeding diversity (ID) to indicate the feeding strategy of the species and how both variables were related. The ID and PD indices were determined by using the following equations:

$$
\begin{gathered}
\mathrm{ID}=\left(-\Sigma \mathrm{P}_{\mathrm{ij}} \cdot \ln \mathrm{P}_{\mathrm{ij}}\right) / \mathrm{N} \\
\mathrm{PD}=\Sigma \mathrm{P}_{\mathrm{i}} \cdot \ln \mathrm{P}_{\mathrm{i}}
\end{gathered}
$$

where $\mathrm{N}=$ the total number fish; $\mathrm{P}_{\mathrm{ij}}=$ the proportion of prey type $i$ in the $j$ th fish and $\mathrm{P}_{\mathrm{i}}=$ the proportion of prey type $i$ in the entire fish samples.

The diet overlapping index $(\mathrm{C} \lambda)$ as proposed by Morisita and modified by Horn (1966) was applied for rivers where more than one species was found. In turn, the Shannon (H') index was used to measure trophic diversity or niche width for each of the sampling sites. The niche width is a measure of the range or diversity of the resources used by a species in used habitats (Crowder, 1990). Cluster analysis was performed by using the unweighted pair group average (UPGMA) as the linkage method (Sokal \& Sneath, 1963; Crisci \& Armengol, 1983). The "IA" percentage for each food item was used to calculate the Pearson correlation coefficient (Sokal, 1961) to describe the similarity of diets for the species under study. Differences between trophic groups separated by the cluster analysis were tested by similarity analysis (ANOSIM). In addition importance of prey category in different trophic groups were assessed by the percentage of similarity analysis (SIMPER) procedure which determines the reponsible prey categories for the resulting grouping by the cluster analysis. Multivariate analyses were performed using the statistical package PAST (version 1.99, Hammer et al., 2001). Voucher specimens are deposited in the fish collection of Museo Argentino de Ciencias Naturales "Bernardino Rivadavia", Buenos Aires, Argentina (MACN-Ict).

\section{Results}

Environmental conditions of study streams reflected those typically expected for mountains streams. Conductivities were low, varying between 19 and $67 \mu \mathrm{S} / \mathrm{cm}$, and dissolved oxygen and temperature ranged from 7.7-10.2

Table 1. Main environmental characteristics and species density by study sites. $\mathrm{P}: \mathrm{R}=$ pool - riffle ratio; $\mathrm{A}=$ altitude $($ masl); $\mathrm{Z}=$ mean depth $(\mathrm{m}) ; \mathrm{T}=$ mean temperature $\left({ }^{\circ} \mathrm{C}\right) ; \mathrm{K}=$ mean conductivity $(\mu \mathrm{S} / \mathrm{cm}) ; \mathrm{O}^{2}=$ dissolved oxygen $(\mathrm{mg} / \mathrm{l}) ; \mathrm{SF}=$ Salvelinus fontinalis $\left(\right.$ fish $\left./ \mathrm{m}^{2}\right) ; \mathrm{OM}=$ Oncorhynchus mykiss $\left(\mathrm{fish} / \mathrm{m}^{2}\right) ; \mathrm{S}=\operatorname{salmonid}\left(\mathrm{fish} / \mathrm{m}^{2}\right) ; \mathrm{TC}=$ Trichomycterus corduvensis $\left(\mathrm{fish} / \mathrm{m}^{2}\right)$.

\begin{tabular}{lccccccccccccc}
\hline River & $\#$ & Order & $\mathrm{P}: \mathrm{R}$ & $\mathrm{A}$ & $\mathrm{Z}$ & $\mathrm{pH}$ & $\mathrm{T}$ & $\mathrm{K}$ & $\mathrm{O}^{2}$ & $\mathrm{SF}$ & $\mathrm{OM}$ & $\mathrm{S}$ & $\mathrm{TC}$ \\
\hline Achala & 1 & 3 & 1.8 & 1850 & 20 & 8.82 & 13 & 39 & 8.2 & 0.16 & & 0.16 & \\
Chabela & 2 & 3 & 2.33 & 1900 & 60 & 7.97 & 13 & 49 & 8.7 & 0.15 & & 0.15 \\
Cienaga & 3 & 3 & 0.67 & 2032 & 33 & 8.55 & 13.6 & 54 & 9.4 & 0.07 & & 0.07 & \\
Comelleras & 4 & 1 & 0.85 & 2270 & 25 & 7.9 & 6.9 & 41 & 9.9 & & & & 0.01 \\
Condorito & 5 & 3 & 1.50 & 2060 & 34 & 8 & 12.5 & 44 & 9.1 & 0.02 & 0.055 & 0.075 & \\
Cristal & 6 & 2 & 0.35 & 2150 & 25 & 8.1 & 9.4 & 57 & 8.7 & & & & 0.01 \\
Las Ensenadas & 7 & 3 & 1.33 & 2025 & 30 & 8.28 & 12 & 49 & 8.5 & & & & \\
Jaime & 8 & 4 & 0.33 & 1500 & 40 & 8.84 & 16.6 & 54 & 7.9 & & 0.03 & 0.03 & 0.03 \\
Las Lomitas & 9 & 2 & 0.08 & 2130 & 48 & 8.7 & 8.8 & 30 & 8.4 & 0.02 & & 0.02 & \\
Malambo & 10 & 4 & 1.00 & 1513 & 50 & 7.6 & 17 & 51 & 10.1 & & 0.07 & 0.07 & \\
Piedras & 11 & 4 & 0.86 & 2047 & 42 & 9.13 & 13.5 & 38 & 9.4 & 0.09 & & 0.09 & \\
San Guillermo & 12 & 4 & 0.70 & 1869 & 65 & 8.9 & 13.1 & 67 & 9.5 & & & & 0.05 \\
San Miguel & 13 & 1 & 0.52 & 1975 & 40 & 8.16 & 13.6 & 19 & 8.3 & 0,02 & & 0.02 & \\
Las Torrecillas & 14 & 1 & 2.00 & 2009 & 60 & 7.3 & 12.1 & 54 & 8.1 & & & & 1.9 \\
Trinidad & 15 & 1 & 1.17 & 2040 & 40 & 8 & 11.5 & 28 & 9.0 & 0.05 & & 0.05 & \\
Paso de Guanaco & 16 & 3 & 1.25 & 2200 & 45 & 7.5 & 11.7 & 35 & 7.8. & 0.01 & & 0.01 & \\
Los Tabaquillos & 17 & 2 & 1.17 & 2249 & 37 & 7.1 & 8.8 & 37 & 7.7 & & 0.09 & 0.09 & \\
Tres Arboles & 18 & 2 & 0.6 & 1500 & 35 & 8.5 & 16.8 & 66 & 10.2 & & 0.03 & 0.03 & \\
Paso del Negro & 19 & 2 & 0.55 & 1240 & 50 & 6.5 & 17.2 & 55 & 9.9 & & & & 0.63 \\
Antena & 20 & 2 & 0.5 & 2025 & 38 & 8.8 & 12.2 & 30 & 8.5 & 0.03 & & 0.03 & \\
Hornillos & 21 & 2 & 0.45 & 2017 & 43 & 8.9 & 11.5 & 33 & 8.4 & & & &
\end{tabular}


$\mathrm{mg} / \mathrm{l}$ and $6.9-17^{\circ} \mathrm{C}$ (Table 1). In turn, pool: riffle ratio showed large variation which was probably associated to stream slope being mean depth for all habitats units generally $<0.5$ $m$ depth. We were able to identify three common species in sampled rivers: Trichomycterus corduvensis Weyenberg, 1877 and two exotic salmonids such as Salvelinus fontinalis (Mitchill, 1814) and Oncorhynchus mykiss (Walbaum, 1792). Among recognized species, S. fontinalis was detected in 53\% of sampled streams, but in only one was found with $O$. mykiss. In turn O. mykiss and T. corduvensis were recorded in $32 \%$ of streams, both occurring in two streams. No sites were identified having all three species. We also found occasional species such as Astyanax eigenmanniorum (Cope, 1894), Bryconamericus iheringii (Boulenger, 1887) and Jenynsia multidentata (Jenyns, 1842) (less than 3 individuals).

Species distribution showed some differences across altitude although apparent overlapping was evident. Whereas S. fontinalis was never found below $1800 \mathrm{~m}, O$. mykiss and $T$. corduvensis were recorded at all the altitude range. Unlike $O$. mykiss which were found in almost all study bains, S. fontinalis distribution was restricted to only two basins. Salmonids mean density was rather low ranging from 0.01 to $0.16 \mathrm{fish} / \mathrm{m}^{2}$ (Table 1) being maximum at third order streams (Fig. 2). In turn $S$. fontinalis density showed an inverse and significant relationship with altitude $(\mathrm{r}=-0.80 ; \mathrm{p}<0.05)$ (Fig. 3). On the other hand density for overall salmonid populations was directly associated to pool: riffle ratio (Fig. 4). Streams with inhabited by salmonids and T. corduvensis showed some differences based on measured limnological parameters. For example T. corduvensis was recorded in narrower streams $(\mathrm{p}<0.001)$, with higher temperature $(p<0.01)$, more conductivity $(p<0.001)$ and more oxygen $(p<0.001)$. Any of these parameters however appeared as exhibiting limiting values for salmonids during study period.

In order to assess on what extent overlapping in geographic distribution could be also reflected by trophic interactions we analyzed food items in both exotic and native species. For most cases fish stomachs exhibited differences in diet items. The

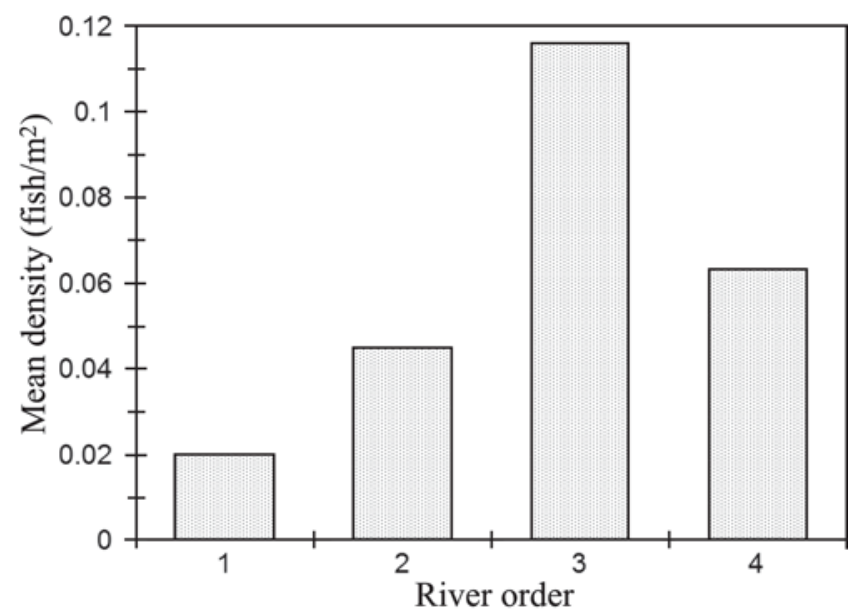

Fig. 2. Mean salmonid density related to river order. greatest vacuity index was found for $T$. corduvensis with percentages ranging between 11 and $33 \%$; and for $S$. fontinalis with only $5 \%$ in Las Lomitas stream. Chironomid larvae represented the main item for T. corduvensis in Paso del Negro, Jaime, Hornitos and Comelleras streams, followed by Trichoptera larvae and Sigara sp. In San Guillermo stream odonata nimphs, Trichoptera larvae and chironomid larvae were the most important food item. In turn, oligochaeta, odonata nymphs and chironomid larvae predominated in Torrecillas stream.

Diet of $S$. fontinalis in La Cienaga, Trinidad and Las Piedras streams was mainly represented by coleoptera larvae (Dyticidae) followed by odonata nimphs, chironomid larvae and amphipods. In Condorito and El Guanaco streams most important diet items were odonata nimphs, followed by amphipods and coleoptera larvae. The Helicopsyche sp. larvae represented the main food item in Las Lomitas and Achala streams, followed by odonata nimphs and adult of Coleoptera. In San Miguel and Antenas streams, amphipods appeared as the dominant items followed by Helicopsyche sp. and insects. Chironomid larvae and odonata nymphs represented the dominant food in the Chabela stream.

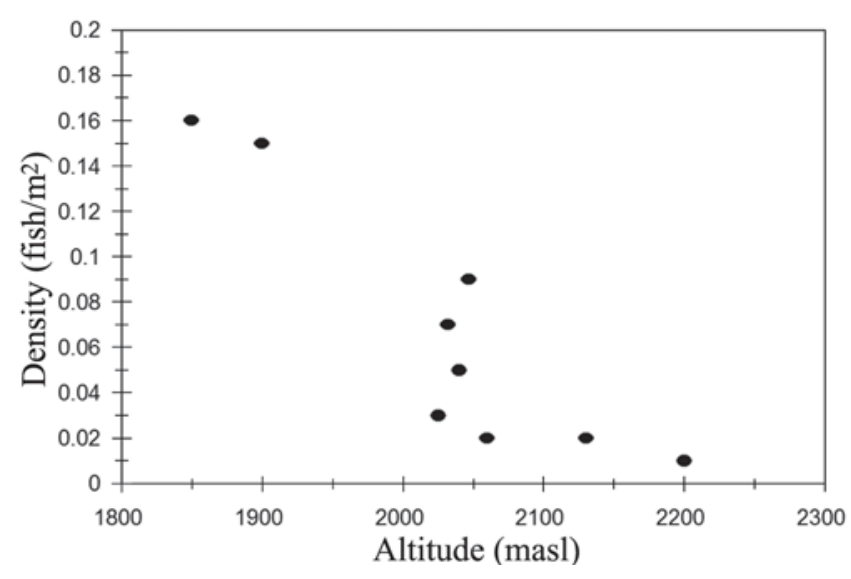

Fig. 3. Relationship between altitude and brook trout density $(\mathrm{r}=0.9 ; \mathrm{F}<0.001)$.

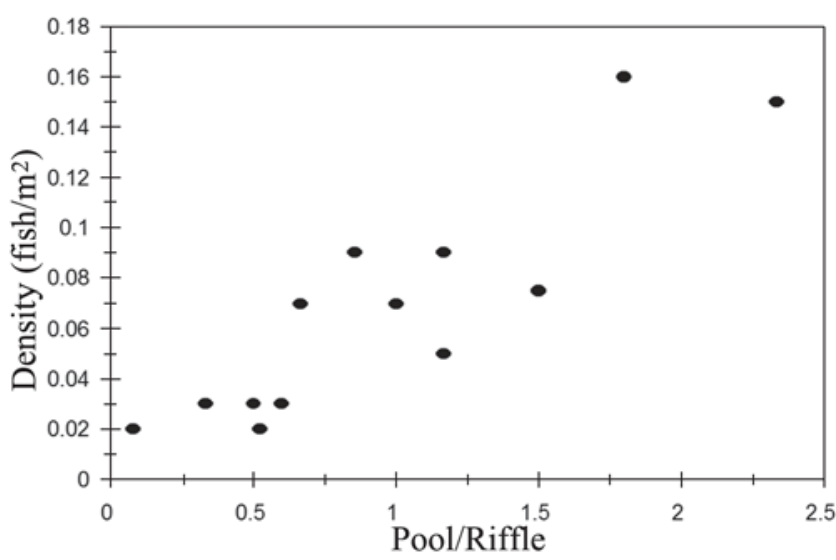

Fig. 4. Relationship between pool: riffle ratio and salmonid density $(\mathrm{r}=0.90 ; \mathrm{F}<0.001)$. 
For O. mykiss in the Condorito and Malambo streams the most important food item were chironomid larvae, trichoptera larvae, insects and Belostoma sp. Secondary food items were dominated by algae, Ephemeroptera and plechopterae nimphs, coleopterae and tipulidae larvae. In the Tabaquillos stream main items were Helicopsyche sp. and Ephemeroptera nimphs, whereas secondary food was represented by Hydrophilidae, insects and odonata nimphs. In turn, in the Tres Arboles stream O. mykiss consumed adults of simulids and heteropters in most of analyzed stomachs. Secondary items were insects and trichoptera larvae. In San Guillermo stream, odonata nimphs represented the predominant item being Sigara sp. and trichoptera larvae occasional items as well. In the Jaime and San Guillermo streams this species predated on $T$. corduvensis $(\% \mathrm{IA}=13.38)$, being however odonata nymphs the dominant food. Values of trophic niche amplitude showed that in almost all streams food items were highly diverse except in San Guillermo stream where $O$. mykiss and T. corduvensis showed very low values.

Two main groups were recognized through cluster analysis. A first group of streams (a) comprised those with high diet similitude between $T$. corduvensis and $O$. mykiss whereas the second group (b) consisted of streams with high diet similitude between $O$. mykiss and $S$. fontinalis diets (Fig. 5). At a finer scale we identified up to six groups which may define the trophic preferences and food source availability in sampled streams, ANOSIM analysis showed a significant separation between these groups $(\mathrm{R}=0.6924 ; \mathrm{n}=22 ; \mathrm{p}<0.0001)$. Thus, $T$. corduvensis in the Torrecilla stream and O. mykiss in the Tres Arboles stream defined two unique groups that differed from others due to the intake of oligoquets and simulids respectively (contribution \% by SIMPER $=77.19 \%-88.86 \%$ respectively). The third and most numerous group comprised fish that consumed chironomid larvae as a common food item (39.7\%). The fourth group allowed to identify the dominant presence of $S$. fontinalis, eating amphipods as its main food source $(56.3 \%)$. In turn Helicopsyche sp. $(42.33 \%)$ was the dominant item for $S$. fontinalis defining the fifth group, whereas the sixth group included both $S$. fontinalis and $O$. mykiss which consumed odonata nymphs and dyticid larvae (50.4\% and 49.46\%).

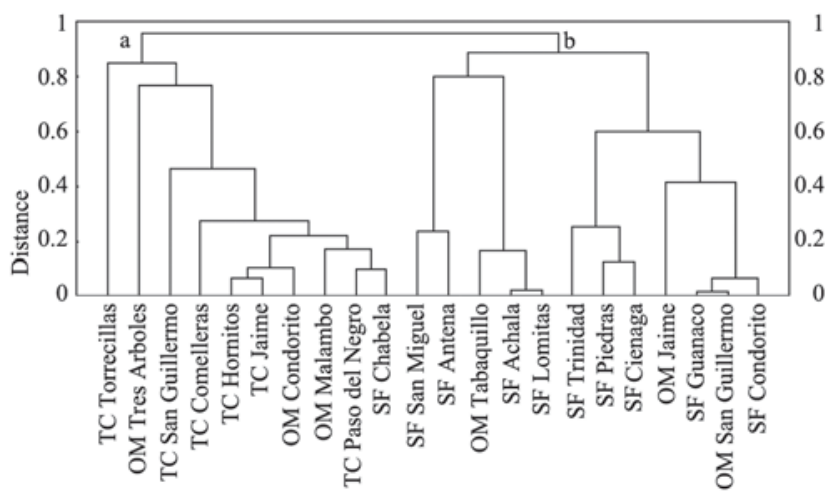

Fig. 5. Dendrogram of diet similitude of Trichomycterus corduvensis (TC), Salvelinus fontinalis (SF) and Oncorhynchus mykiss (OM) in high altitude streams in Pampa de Achala area, Córdoba.
In general $O$. mykiss exhibited a wide trophic niche that ranged between 1.71 and 2.63 except in Jaime and San Guillermo streams. This was the only case where both native exotic species coexisted being odonata nimphs (Anisoptera) the main food item. In the case of T. corduvensis trophic niche values ranged between 1.18 and 3.49, with the exception of San Guillermo stream (0.55), where this species consumed zigoptera nimphs, insects, chironomid and trichoptera larvae. Only $O$. mykiss shared a few stream with other species such as $S$. fontinalis in the Condorito stream exhibiting a low overlapping value $(\mathrm{C} \lambda=0.017)$ and with $T$. corduvensis in the Jaime $(\mathrm{C} \lambda=0.063)$ and San Guillermo $(\mathrm{C} \lambda=$ $0.001)$ streams. Comparative analysis of trophic niche width showed a noticeable similitude among mean values but $S$. fontinalis exhibited the narrowest niche whereas T. corduvensis appears as having the highest mean niche width and variability (Fig. 6). In turn analysis of ID and PD by applying a Tokeshi plot revealed that $T$. corduvensis ranged from specialist to generalist. In turn both salmonids showed generalist feeding habits with a heterogeneous diet although in some streams they appeared as being generalist homogeneous.

\section{Discussion}

This and previous studies show that high altitude streams in the Sierras Grandes region represent an area of marginal distribution for native species but several streams exhibited permanent salmonids populations (Bistoni \& Hued, 2002;
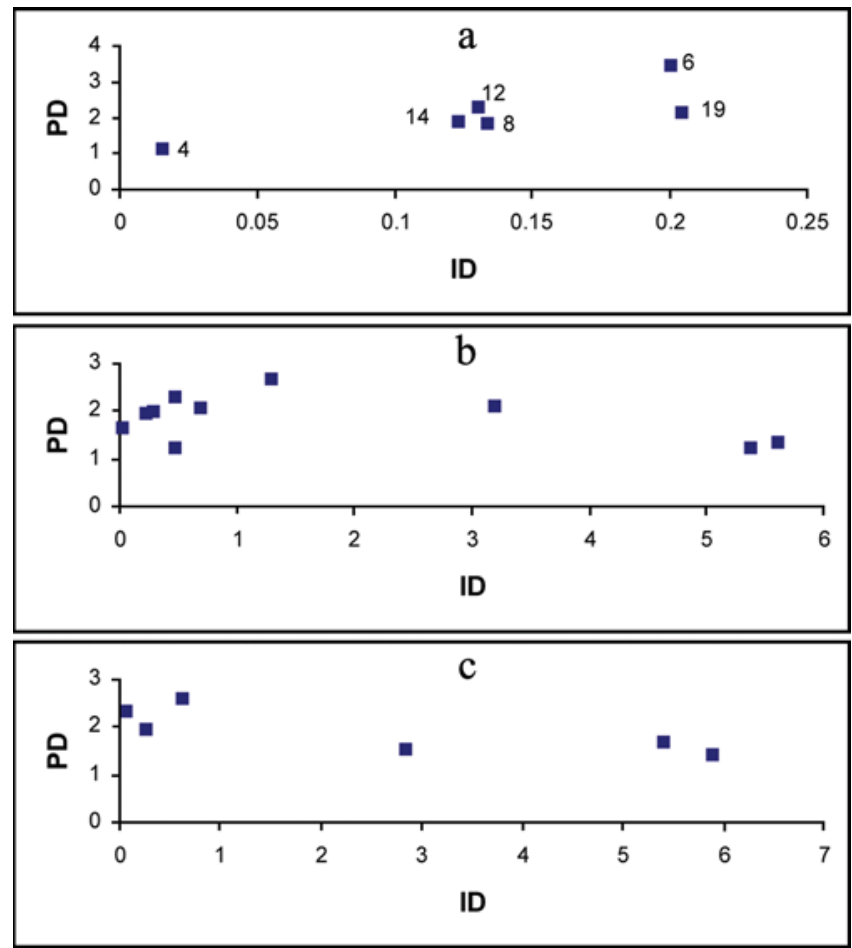

Fig. 6. Graphic representation of Tokeshi analysis. ID = mean individual feeding diversity; $\mathrm{PD}=$ population feeding diversity. a) Trichomycterus corduvensis, b) Salvelinus fontinalis, and c) Oncorhynchus mykiss. Numbers correspond to streams from Table 1. 
Hued \& Bistoni, 2007). Such low fish richness appears as a characteristic attribute of high altitude streams in Pampa de Achala area. Based on morphometric characteristics (mean width $=8 \mathrm{~m}$ ), we were confident that our sampling design fit within recommended efforts to obtain a representative description of fish community, covering in most cases between 30 and 40 channel widths (Lyons, 1992; Reynolds et al., 2003; Temple \& Parsons, 2008). Most streams belong to headwaters basins, and therefore first and second order streams become the dominant riverscape. Stream segments located outside the National Park exhibit impaired riparian areas due to ranching activity that have changed the vegetation structure (Cingolani et al., 2003). This may be an important factor affecting salmonid abundance which has been shown as negatively associated to lack of riparian vegetation (Dales Jones et al., 1999) and inflow of woody debris (Bryant, 1983; Dollof, 1986; MacMahon \& Hartman, 1989). Such conditions reduce cover for salmonids (Heifetz et al., 1986) and pool formation in streams (Andrus et al., 1988). Salmonid density in Pampa de Achala streams was within the lower range value reported for several streams of different areas of United Sates (e.g., Platts \& McHenry, 1988; Flebbe,1994), despite in some cases great differences with other headstreams inhabited by brook and rainbow trout (Neves \& Pardue, 1983; Waters, 1983) were noted. Comparisons however are rather speculative since differences in fish density among streams can be accounted by several major factors such as geology, climate and hydraulics, water fertility (Waters, 1982) as well as habitat unit structure at a smaller scale (Platts \& McHenry, 1988). Future effort in this area should be devoted to obtain production estimates, since this parameter is the best descriptor of fish population status and therefore are important for management decisions (Kwak \& Waters, 1997).

In Pampa de Achala streams S. fontinalis during study period inhabits higher elevation streams than O. mykiss and $T$. corduvensis, which in turn showed considerable overlapping in their distribution by altitude. Both salmonids exhibited a high degree of sympatric distribution, although $S$. fontinalis was not found in streams lower than $1800 \mathrm{~m}$. In turn, in four rivers located in Córdoba Province Bistoni \& Hued (2002) found that T. corduvensis were mostly distributed up to $1000 \mathrm{~m}$ height whereas $O$. mykiss were found in higher altitudes. These authors concluded that altitude plays a significant role in accounting for longitudinal species distribution. In turn Hued \& Bistoni (2007) considered that $O$. mykiss is restricted to only upper basin streams due to thermal limitations although these authors included only lower altitude streams. Since the Pampa de Achala region represents an area of marginal distribution for salmonids, distribution and stream colonization is probably related strongly to propagule pressure coupled with a environmental constraints.

This pattern agrees with what was observed at other high and cold basin areas (Rahel \& Hulbert, 1991; Flebbe, 1994; Taniguchi et al., 1998). Platts \& McHenry (1988) showed that $O$. mykiss was well adapted to a greater range of stream habitats, which supports our finding that this species was found across different altitudes in Pampa de Achala streams. Since temperature was inversely related to stream altitude in our study sites $(r=-0.87 ; \mathrm{p}<0.01)$ we concur that this could be a relevant factor for excluding brook trout from sympatric distribution at high stream altitudes (Fausch, 1988). However we contend that temperature was probably not the unique limiting factor to account for salmonids segregation during the sampling period, since $S$. fontinalis and $O$. mykiss exhibit similar chronic and acute temperature (Todd et al., 2008). Larson \& Moore (1985) noted that sympatry between both species was also related to stream length and Clark \& Rose (1997) concluded that rainbow trout dominance over brook trout in Appalachian streams was related to factors such fecundity and year class failures. In turn, Bustard \& Narver (1975) stated that salmonid density is mostly affected by winter habitats rather than summer rearing habitats. Since temperature was not a limiting factor during winter season, both native and exotic species have the potential for coexisting in Pampa de Achala streams, providing the opportunity to analyze on what extent they could interact. Also geomorphic features should be taken into account since they may vary between season according to flow. The direct and significant relationship between brook trout and pool/riffle ratio may be considered as indicative of habitat quality, despite a 1:1 ratio was considered as optimum (Raleigh, 1982). Flebbe (1999) for example reported preference of brook trout for pool habitats in Appalachian streams whereas Hankin \& Reeves (1988) found higher densities of salmonids in pools than in riffles. On the other hand hydrological characteristics may favor the dominance of either rainbow or brook trout depending on the predominance of slow or fast flows (Cunjak \& Green, 1984). Understanding salmonid distribution patterns in areas where native species are scarce should be therefore a major focus in high altitude rivers from Córdoba Province. Geomorphic, climatic and hydrological features have been recognized as major factors governing regional salmonid distribution (Nelson et al., 1992; Rahel \& Nibbelink, 1999) as well as production and biomass (Scarnecchia \& Bergersen, 1987) and could be used as cues for refining abundance and distribution patterns prediction of such species in future studies.

Analysis of food characteristics showed that T. corduvensis consumed bentonic organisms associated with aquatic vegetation as its main food resource. Main items comprised chironomid larvae, with the exception of the Torrecillas stream where oligochaeta and zigoptera represented the main food resource. However trichoptera larvae, odonata nimphs and heteroptera were also important components, whereas algae, amphipods, ephemeroptera nimphs, hirudinea and coleoptera larvae represented a secondary food source. This siluriform behaves as a bentonic insectivorous fish as was also noted by Ferriz (1998) in San Luis Province rivers analyzing the trophic patterns of Trichomycterus areolatus (Duarte et al., 1971; Ruiz \& Berra, 1994) and Hatcheria macraei (Ferriz, 1994). Such species exhibited similar environmental preferences such as $T$. corduvensis, capturing their food items based on hunting speculation and grubbers excavating while moving (Sazima, 1986). 
For S. fontinalis inhabiting the Pampa de Achala streams the dominant food source was odonata nimphs, amphipods, coleoptera, chironomids and trichoptera larvae whereas Helicopsyche sp., amphipods and anisoptera nymphs were identified as secondary food items. We were not able to detect native fish in their stomachs or amphibians, despite the fact that these organisms were very abundant, particularly in all sampled streams. The basic trophic behavior of $S$. fontinalis in freshwater bodies in Argentina however is still not well known (Macchi et al., 1999; Milano et al., 2002). Generally, adults of $S$. fontinalis show a carnivorous-euriphagous diet consuming invertebrates and fish in an opportunistic way according to prey availability (Power, 1980; Macchi et al., 1999; Milano et al., 2002). In lotic environments however this salmonid consumes mostly bentonic and drift invertebrates.

On the other hand the diet of $O$. mykiss has been well analyzed mostly in Patagonian lakes and streams in order to detect its impact on native species. Barriga et al. (2007) claimed that $O$. mykiss had displaced native fish fauna for several streams whereas Macchi et al. (2007) noted a more piscivorous diet for $O$. mykiss than for $S$. fontinalis, when prey abundance was limited. However Ferriz, (1993/94), Grosman (1993/94) and Macchi et al. (1999) considered that O. mykiss behaves as an opportunistic generalist. This pattern is similar to that observed in the Pampa de Achala streams, where the dominant food items in the study sites were odonata nimphs, chironomid larvae, trichoptera larvae, T. corduvensis, coleoptera, ephemeroptera nimphs and simulids. Secondary food intake included coleoptera larvae, amphipods, diptera larvae and terrestrial adult insects. As in the case of $S$. fontinalis, we did not record amphibians in stomach contents in any stream.

Species such as $O$. mykiss and T. corduvensis were found sharing the same habitats in only two streams, San Guillermo and Jaime where predation on T. corduvensis was recorded. In San Guillermo stream, the trophic niche width was the lowest for both species. However, in Jaime stream the trophic niche of $O$. mykiss was of moderate value $(\mathrm{H}=1.55)$ showing a low overlapping diet index $(\mathrm{C} \lambda=0.06)$. In this stream, $T$. corduvensis also exhibited a moderate niche width index. In turn, in San Guillermo stream the trophich niche of O. mykiss was much narrow $(\mathrm{H}=0.22)$ as well as diet overlapping index $(\mathrm{C} \lambda=0.001)$.

However salmonids may impact not only by direct predation but also through competition for trophic resources (Fernández \& Fernández, 2003). Salmonids species prey on aquatic invertebrates during light hours (McIntosh et al., 1992), increasing primary production and nutrient availability (Huryn, 1998; Townsend, 2003). Buria et al. (2007) observed in three low order streams in Patagonia that $O$. mykiss modified the biomass and length composition of bentonic macroinvertebrates. Previous studies on T. corduvensis in the San Luis and Córdoba Provinces (Ferriz, 1998; Dillon \& Haro, 2002) indicated that T. corduvensis used nimphs and aquatic larvae of ephemeroptera, chironomids and simulids as the main food source in the same vein as salmonids. In two streams from Tucumán Province Molinari (2008) found that benthos composition and diversity differed between streams inhabited by $O$. mikyss and without it.
Pianka (1982) considered that niche amplitude decreases with resource availability implying that in those water bodies or annual seasons when food source decreases, fish tend to increase the trophic niche. This may explain why $T$. corduvensis showed a wider niche than salmonids perhaps as an adaptive response to compensate for food resource competition. On the other hand such pattern may account for the inverse relationship observed between the diet diversity index of $S$. fontinalis and river order. The fact that our results corresponded to a low temperature season allow fish to express their full capacity for food searching. Thermal characteristics of study streams during winter season appear as being within the preferenda for both rainbow and brook trout (Raleigh, 1982, Raleigh et al., 1984), but such conditions could change during summer where higher temperatures in study streams could exert influence on salmonid distribution. It is known that temperature is an important factor constraining feeding behavior and promoting diet shifting (Lattimore \& Gibbons, 1976). We recognize however that during winter season trophic conditions of study streams could differ from summer food resources availability, thus requiring more extensive analysis. Although we found that O. mykiss predated on T. corduvensis in two streams inhabited by both species, their narrow niches suggest that trophic overlapping was not so evident. They consume similar preys as odonata and chironomids as was portrayed by cluster analysis (group 3) but salmonids exhibits a homogenous and heterogeneous generalist habit, being therefore well adapted to taker advantage of broader prey availability. In turn potential of direct predation on $T$. corduvensis probably could shift habitat use by this species relaxing food competition. Analysis derived from niche width patterns suggests that in $T$. corduvensis population niche width increases as a result of increases in individual niche width meaning that individuals can increase their own niche width by shifting to use a different abundant prey types. A similar pattern was noted by Bolnick et al. (2010) as Oncorhynchus clarkii was introduced in stream inhabited by Gasterosteus aculeatus (stickleback) promoting an increase in population niche width. However since in only two streams this species coexisted with salmonids is not possible to extract definitive conclusions about niche shift due to their presence at least during the study period.

In the case of salmonids we noted that in S. fontinalis no significant relationship was noted between ID and PD indicating that population niche width did not increase or decrease as individual niche increases. This species showed a homogeneous generalist feeding habit. However, for $O$. mykiss the population niche width appeared as be negatively related to increase of individual niche width suggesting a decrease in specialization. Thus this species exhibited a more heterogeneous generalist habit.

Unfortunately, there is a lack of information regarding the distribution of native species distributed before salmonids were introduced. This makes it difficult to determine whether scarcity of native species in study streams can be attributed to salmonid impacts or whether they are more related to 
zoogeographic barriers and environmental limitations. In the Ceballos stream for example where salmonids have not been yet recorded $T$. corduvensis is widely distributed with high abundance (Juncos et al., 2006). Clearly more information should be gathered by increasing the number of sampled streams within different orders, expanding the number of stream reaches and segments and also including warm water periods, where thermal limitations and differences in habitat availability could show a rather different distribution pattern and potential for species interaction.

\section{Acknowledgements}

We acknowledge Lucía del Valle Ruiz, Julio Monguillot y Regina Losada from the Nacional Park Administration (Central Regional Office) and Darío Ramírez and the Park Rangers Corp from Quebrada del Condorito National Park. We also acknowledge the province park rangers Julio Guevara and Walter González of the Córdoba Environmental Agency. Finally, we are indebted with our three field work assistants, Oscar Gonzáles, Mauricio Lizulli and Andrés Losada for all their effort.

\section{Literature Cited}

Andrus, C. W., B. A. Long \& H. A. Froehlich. 1988. Woody debris and its contribution to pool formation in a coastal stream 50 years after logging. Canadian Journal of Fisheries and Aquatic Sciences, 45: 2080-2086.

Ault, T. R. \& R.W. White. 1994. Effects of habitat structure and the presence of brown trout on the population density of Galaxias truttaceus in Tasmania, Australia. Transaction of American Fisheries Society, 123: 939-948.

Baigún, C. \& R. Quirós. 1985. Introducción de peces exóticos en la República Argentina. Informes Técnicos del Depto. de Aguas Continentales $\mathrm{N}^{\circ}$ 2. Mar del Plata, Argentina, Instituto Nacional de Investigación y Desarrollo Pesquero, 90p.

Bain, M. B. \& N. J. Stevenson. 1999. Aquatic habitat assessment. Maryland, American Fisheries Society, 216p.

Barriga, J. P., M. A. Battini \& V. E. Cussac. 2007. Annual dynamics variation of a landlocked Galaxias maculatus (Jenyns, 1842) population in a Northern Patagonian river: occurrence of juveniles upstream migration. Journal Applied of Ichthyology, 2: 1-8.

Berg, J. 1979. Discussion of methods of investigation the food of fishes, with reference to a preliminary study of the prey of Gobiusculus flavescens (Globiidae). Marine Biology, 50: 263-273.

Bisson, P. A., J. L. Nielson, R. Palmason \& L. E. Grove. 1982. A system of naming habitat types in small streams with examples of habitat utilization by salmonids during low stream flow. Pp. 62-73. In: Armantrout, N. A. (Ed.). Acquisition and utilization of aquatic habitat inventory information. Maryland, American Fisheries Society.

Bistoni, M. A. \& L. Hued. 2002. Patterns of fish species richness in rivers of the central region of Argentina. Brazilian Journal of Biology, 62: 353-364.

Bolnick, D. I., T. Ingram, W. E. Stutz, L. K. Snowberg, O. L. Lau \& J. S. Paull. 2010. Ecological release from interspecific competition leads to decoupled changes in population and individual niche width. Proceeding of The Royal Society B., doi:10.11098/rspb.2010.0018.
Bryant, M. 1983. The role and management of woody debris in west coast salmonid nursery streams. Norht American Journal Fish Management, 3: 322-330.

Buria, L., R. Albariño, V. Díaz Villanueva, B. Modenutti \& E. Balseiro. 2007. Impact of exotic rainbow trout on the benthic macroinvertebrate community from Andean-Patagonian headwater streams. Archiv für Hydrobiologie, 168: 145-164.

Bustard, D. R. \& D. W. Narver. 1975. Aspects of the winter ecology of juvenile coho salmon (Oncorhynchus kissutch) and steelhead trout (Salmo gairdneri). Jounal Fisheries Research Board of Canadian, 32: 667-680.

Cingolani, A. M., M. R. Cabido, D. Renison \& V. Solís Neffa. 2003. Combinaed effects of environment and grazing on vegetation structure in Argentine granite grassland. Jounal of Vegetation Science, 14: 223-232.

Clark, M. E. \& K. A. Rose. 1997. Factors affecting competitive dominance of rainbow trout over brook trout in Southern Appalachian streams: implications of an individual-based model. Transactions of the American Fisheries Society, 126: 1-20.

Crisci, J. V. \& M. F. L. Armengol. 1983. Introducción a la teoría y práctica de la taxonomía numérica. Washington, OEA, Serie de Biología, Monograf. $\mathrm{N}^{\circ} 26,132 \mathrm{p}$.

Crowder, L. B. 1990. Community Ecology. Pp. 609-632. In: Schedeck, C. D. \& P. B. Moyle (Eds.). Methods for Fish Biology. Maryland, American Fisheries Society, 684p.

Cunjak, R. A. \& J. M. Green. 1984. Species dominance by brook trout and rainbow trout in a simulated stream environment. Transactions of the American Fisheries Society, 113: 737-743.

Dales Jones III, E. B., G. S. Helfman, J. O. Harper \& P. V. Bolstad. 1999. Effects of riparian forest removal on fish assemblages in Southern Appalachian streams. Conservation Biology, 13: 1454-1465.

Dillon, C. E. \& J. G. Haro. 2002. La alimentación del bagrecito serrano Trichomycterus corduvense (Pisces, Trichomycteridae) en el río Anizacate (Córdoba, Argentina). Natura Neotropicalis, 33: 31-38.

Dollof, C. A. 1986. Effects of stream clearing on juvenile coho salmon and Dolly Varden in Southeast Alaska. Transactions of the American Fisheries Society, 115: 743-755.

Duarte, W., R. Feito, C. Jara \& E. Orellana. 1971. Ictiofauna del sistema hidrográfico del río Maipo. Boletín del Museo Nacional de Historia Natural, 32: 227-268.

Fausch, K. 1989. Tests of composition between native and introduced salmonids in streams: what have we learned?. Canadian Journal of Fisheries and Aquatic Sciences, 45: 2238-2246.

Fernández, H. R. \& L. A. Fernández 1995: La Biodiversidad del Zoobentos en ríos de montaña de Tucumán, la trucha como amenaza. Pp. 149-146. In: Brown, A. D. \& H. R. Grau (Eds.). Investigación, Conservación y Desarrollo en Selvas Subtropicales de Montaña. Tucumán, Ediciones Tucumán, $270 \mathrm{p}$.

Ferriz, R. A. 1993/94. Algunos aspectos de la dieta de cuatro especies ícticas del río Limay (Argentina). Revista de Ictiología, 2/3: 1-7.

Ferriz, R. A. 1994. Alimentación de Olivaichthys viedmensis (Mac Donagh, 1931) y Hatcheria macraei (Girard, 1855) (Teleostei, Siluriformes) en el río Limay, Argentina. Naturalia Patagónica, Ciencias Biológicas, 2: 83-88.

Ferriz, R. A. 1998. Alimentación de Trichomycterus corduvense Weyenberg, 1870 (Teleostei: Trichomycteridae) en dos ríos serranos de San Luis, Argentina. Revista Museo Argentino de Ciencias Naturales, Hidrobiología, 8: 43-49. 
Flebbe, P. A. 1994. A regional view if the marginal salmonid abundance and distribution in the Southern Appalachian mountains of North Carolina and Virginia. Transactions of the American Fisheries Society, 123: 657-667.

Flebbe, P. A. 1999. Trout use of woody debris and habitat in Wine Spring Creek, North Carolina. Forest Ecology and Management, 114: 367-376.

Flecker, A. S. \& C. R. Townsend. 1994. Community-wide consequences of trout introduction in New Zealand streams. Ecological Applications, 4: 798-807.

Grosman, M. F. 1993/94. Interacciones tróficas entre trucha arco iris (Oncorhynchus mykiss), pejerrey patagónico (Patagonina hatcheri) y perca (Percichthys trucha) en un ambiente patagónico. Revista Asociación de Ciencias Naturales del Litoral, 24/25: 15-25.

Hammer, O., D. A. T. Harper \& P. D. Ryan. 2001. PAST: Paleontological Statistics Software Package for Education and Data Analysis. Palaeontologia Electronica, 4(1): 9p.

Hankin, D. G. \& G. Reeves. 1988. Estimating total fish abundance and total habitat area in small streams based on visual estimation methods. Canadian Journal of Fisheries and Aquatic Sciences, 45: 834-844.

Haro, J. G. \& M. A. Bistoni. 1996. Ictiofauna de la provincia de Córdoba. Pp. 169-190. In: Di Tada, I. E. \& E. H. Bucher (Eds.) Biodiversidad de la provincia de Córdoba, Vol. I, Fauna Universidad Nacional de Río Cuarto (UNRC), Córdoba.

Heifetz, J., M. L. Murphy \& K. V. Koski. 1986. Effects of logging on winter habitat of juvenile salmonids in Alaskan streams. North American Journal of Fisheries Management, 6: 52-68.

Horn, H. S. 1966. Measurement of "overlap" in comparative ecological studies. American Naturalist, 100: 420-424.

Hued, A. C. \& M. A. Bistoni. 2007. Abundancia de las fauna íctica en la cuenca del río Suquía (Córdoba, Argentina). Iheringia, Série Zoologia, 97(3): 286-292.

Huryn, A. D. 1998. Ecosystem level evidence for top-down and bottom-up control of production in a grassland stream system. Oecologia, 115: 173-183.

Hyslop, E. J. 1980. Stomach contents analysis-a review of methods and their application. Journal Fishesries Biology, 17: 411429.

Jackson, P. D. 1981. Trout introduced into southeastern Australia: Their interaction with native species. Victorian Naturalist, 98: 18-24.

Jackson, J., T. Raadik, M. Lintermans \& M. Hammer. 2004. Alien salmonids in Australia: impediments to effective impact management, and future directions. New Zealand Journal of Marine and Freshwater Research, 38: 447-455.

Juncos, R., M. A. Bistoni \& I. Zito Freyer. 2006. Composición y estructura de la ictiofauna del Río Ceballos-Saldan (Córdoba, Argentina). Iheringia, Série Zoologia, 87: 171-180.

Krueger, C. C. \& M. May. 1991. Ecological and genetic effects of salmonid introductions in North America. Canadian Journal of Fisheries and Aquatic Sciences, 48: 66-77.

Kwak, T. J. \& T. F. Waters. 1997. Trout production dynamics and water quality in Minnesota streams. Transactions of the American Fisheries Society, 126: 35-48.

Larson, G. L. \& S. E. Moore. 1985. Enchroament of exotic rainbow trout into stream populations of native brook trout in the southern Appalachian mountains. Transactions of the American Fisheries Society, 114: 195-203.

Lattimore, R. E. \& J. W. Gibbons. 1976. Body condition and stomach contents of fish inhabiting thermally altered areas. American Midland Naturalist, 95: 215-219.
Lyons, J. 1992. The length of stream to sample with a towed electrofishing unit when species richness is estimated. North American Journal of Fisheries Management, 12: 198-203.

Macchi, P. J., V. E. Cussac, M. F. Alonso \& M. A. Denegri. 1999. Predation relationships between introduced salmonids and the native fish fauna in lakes and reservoirs in northern Patagonia. Ecology of Freshwater Fish, 8: 227-236.

Macchi, P. J., M. A. Pascual \& P. H. Vigliano. 2007. Diferencial piscivory of the native Percichthys trucha and exotic salmonids upon the native forage fish Galaxias maculatus in Patagonian Andean lakes. Limnologica, 37: 76-87.

McDowall, R. M. 1990. New Zealand freshwater fishes: a natural history and guide. Auckland, Heinemann Reed, 553p.

McDowall, R. M. 2003. Impacts of introduced salmonids on native galaxiids in New Zealand upland streams: A new look at an old problem. Transactions of the American Fisheries Society, 132: 229-238.

McDowall, R. M. 2006. Crying wolf, crying foul, or crying shame: alien salmonids and a biodiversity crisis in the southern cool temperate galaxioid fishes? Reviews in Fish Biology and Fisheries, 16: 233-422.

McMahon, T. E. \& G. E. Hartman. 1989. Influence of cover complexity and current velocity on winter habitat use by juvenile coho salmon (Oncorhynchus kisutch). Canadian Journal of Fisheries and Aquatic Sciences, 46: 1551-1557.

McIntosh, A. R., C. R. Townsend \& T. A. Crowl. 1992. Competition for space between introduced brown trout (Salmo trutta L.) and a native galaxiid (Galaxias vulgaris Stokell) in a New Zealand stream. Journal Fish Biology, 41: 63-81.

Milano, D., V. E. Cussac, P. J. Macchi, D. E. Ruzzante, M. F. Alonso, P. H. Vigliano \& M. A. Denegri. 2002. Predator associated morphology in Galaxias platei in Patagonian lakes. Journal of Fish Biology, 61: 138-156.

Molinari, C. 2008. Impact of rainbow trout on aquatic invertebrate communities in subtropical mountain streams of northwest Argentina. Ecología Austral, 18: 101-117.

Molinero, A. \& R. Flos. 1992. Influence of season on the feeding habits of the common sole Solea solea. Marine Biology, 113: 499-507.

Nelson, R. L., W. S. Platts, D. P. Larsen \& S. E. Jensen. 1992. Trout distribution and habitat in relation to geology and geomorphology in the north for Humboldt River drainage, northeastern Nevada. Transactions of the American Fisheries Society, 121: 405-426.

Neves, R. J. \& G. N. Pardue. 1983. Abundance and production of fishes in small Appalachian stream. Transactions of the American Fisheries Society, 112: 21-26.

Oda, D. K. \& J. D. Parrish. 1981. Ecology of commercial snappers and groupers intruduced to Hawaiian reefs. Proceeding of the Fourth International Coral Reef Symposium, 1: 59-67.

Pascual, M. A., P. Macchi, J. Urbanski, F. Marcos, C. Rivas Rossi, M. Novoa \& P. Dell'Aciprete. 2002. Evaluating potential effects of exotic freshwater fish from incomplete species presenceabsence data. Biological Invasions, 4: 101-113.

Pascual, M. A. \& J. E. Ciancio. 2007. Introduced anadromous almonids in Patagonia: risks, uses and a conservation paradox. Pp. 333-353. In: Bert, T. M. (Ed.). Ecological and genetic implications of aquaculture activities. New York, Springer.

Pascual, M. A., V. Cussac, B. Dyer, D. Soto, P. Vigliano, S. Ortubay \& P. Macchi. 2007. Freshwater fishes of Patagonia in the $21^{\text {st }}$ Century after a hundred years of human settlement, species introductions, and environmental change. Aquatic Ecosystem Health and Management, 10: 212-227. 
Pianka, E. R. 1982. Ecología Evolutiva. Barcelona, Omega, 365p.

Platts, W. S. \& M. L. McHenry. 1988. Density and biomass of trout and char in western streams. Forest Service, General Technical Report INT-241, Ogden, UT. U. S. Department of Agriculture. Forest Service, Intermountain Research Station, $17 \mathrm{p}$.

Power, G. 1980. The brook charr, Salvelinus fontinalis. Pp. 141203. In: Balon, E. K. (Ed.). Charrs: salmonid fishes of the genus Salvelinus. Dordrecht, Junk Publishers, 928p.

Rahel, F. J. \& W. A. Hulbert. 1991. Fish assemblages and habitat gradients ina Rocky Mountains-Great Plains stream: biotic zonation and additive petterns of community change. Transactions of the American Fishery Society, 120: 319-332.

Rahel, F. J. \& N. P. Nibbelink. 1999. Spatial patterns in relations among brown trout (Salmo trutta) distribution, summer air temperature and stream size in Rocky Mountain streams. Canadian Journal of Fisehries and Aquatic Science, 56 (Suppl.1): 43-51.

Raleigh, R. F. 1982. Habitat suitabiluity index models: Brook trout. U. S. Fish and Wildlife Service, FWS/OBS-82. 19.24

Raleigh, R. F., T. Hickman, R. C. Solomon \& P. C. Nelson 1984. Habitat suitabiluity index models. Brook trout. U. S. Fish and Wildlife Service, FWS/OBS-82. 19.601.

Reynolds, L., A. T. Herlihy, P. H. Kaufmann, S. V. Gregory \& R. M. Hughes. 2003. Electrofishing effort requirements for assessing species richness and biotic integrity in western Oregon streams. North American Journal of Fisheries Management, 23: 450461.

Ruiz, V. H. \& T. M. Berra. 1994. Fishes of the High Biobio of South-Central Chile with notes on the diets and speculations on the origin of the ichthyofauna. Ichthyological Exploration of Freshwaters, 5: 5-18.

Sazima, I. 1986. Similarities in feeding behaviour between some marine and freshwater fishes in two tropical communities. Journal Fish Biology, 29: 53-65.

Scarnecchia, D. L \& E. P. Bergersen. 1987. Trout production and standing crop in Colorado's small streams as related to environmental features. North American Journal of Fisheries Management, 7: 315-330.

Sokal, R. R. 1961. Distance and Measure of Taxonomics Similarity. Systematic Zoology, 10: 71-90.

Sokal, R. R. \& P. H. A. Sneath. 1963. Principles of Numerical Taxonomy. W. H. Freeman, 359p.
Temple, G. \& T. N. Pearsons. 2008. Electrofishing: backpack and drift boat. Pp. 95-132. In: Johnson, D. H., B. M. Schrier, J. A. O’Neal, J. S. Knutsen, X. Augerot, O’Neil \& N. T. Pearsons (Eds.). Salmonids field protocols handbook. Techniques for assessing status and trends in salmon and trout populations. Maryland, American Fisheries Society, 458p.

Taniguchi, Y., F. J. Rahel, D. C. Novinger \& K. G. Gerow. 1998. Temperature mediation of competitive interactions among three fish species that replace each other along longitudinal stream gradients. Canadian Journal of Fisheries and Aquatic Sciences, 55: 1894-1901.

Tilzey, R. D. J. 1976. Observations on interactions between indigenous Galaxiidae and introduced Salmonidae in the Lake Eucumbene catchment, New South Wales. Australian Journal of Marine and Freshwater Research, 27: 551-564.

Todd, A. S, M. A. Coleman, A. M. Konowal, M. K. May, S. Johnson, N. K. Vieira \& J. F. Saunders. 2008. Development of new water temperature criteria to protect Colorado's fisheries. Fisheries 33: 433-443.

Tokeshi, M. 1991. Graphical analysis of predator feeding strategy and prey importance. Freshwater Forum, 1: 179-183.

Townsend, C. R. 2003. Individual population, community and ecosystem consecuences of a fish invader in New Zealand stream. Conservation Biology, 17: 38-47.

Townsend, C. R. \& T. A. Crowl. 1991. Fragmented population structure in a native New Zealand fish: an effect of introduced brown trout?. Oikos, 61: 347-354.

Vigliano, P. \& M. F. Alonso. 2007. Salmonid intriductions in Patagonia: a mixed blessing. In: Bert, T. M. (Ed.). Ecological and genetic implications of aquaculture activities. New York, Springer.

Waters, T. F. 1982. Annual production, production/biomass ratio and the ecotrophic coefficient for manangement of trout in streams. North American Journal of Fisheries Management, 12: 34-39.

Waters, T. F. 1983. Replacement of brook trout by brown trout over 15 years in a Minnesota stream: Production and abundance. Transections of American Fisheries Society, 112: 137-146.

Windell, T. J. \& S. H. Bowen. 1978. Methods for study of fish diets based on analysis of stomach contents. Pp. 219-226. In: Bagenal, T. (Ed.). Methods for assessment of Fish Production in Fresh Water. Oxford, Blackwell Scientific Publications.

Zippin, C. 1958. The removal method of population estimation. Journal of Wildlife Management, 22: 82-90.

Accepted August 18, 2010

Published December 16, 2010 